\title{
Comparison of motives underlying food choice and barriers to healthy eating among low medium income consumers in Uruguay
}

\begin{abstract}
Comparación de los motivos responsables de la selección de alimentos y barreras para una alimentación saludable entre consumidores de ingreso bajo y medio en Uruguay
\end{abstract}

\section{Uma comparação dos motivos subjacentes às escolhas alimentares e das barreiras contra a alimentação saudável entre consumidores de renda baixa e média no Uruguai}

Gastón Ares 1

Leandro Machin 2

Alejandra Girona 3

María Rosa Curutchet 4

Ana Giménez 1 doi: 10.1590/0102-311X00213315

\begin{abstract}
Interventions aimed at changing dietary patterns should be designed based on the main motives underlying the food choices of specific target populations. The aim of the present study was to identify motives underlying food choice and barriers to healthy eating among consumers in two socioeconomic levels in Uruguay. Eleven focus groups were carried out with a total of 76 participants. Six of the groups involved low income participants and the others were conducted with middle income participants. Discussions were held around frequently consumed products, motives underlying food choices and barriers to healthy eating. Results confirmed the strong influence of income level on motives underlying food choice and barriers to the adoption of healthy eating. Low income participants described their choices as mainly driven by economic factors and satiety, whereas convenience was the main determinant of food selection for middle income participants. Implications for the design of public policies targeted at each group are discussed.
\end{abstract}

Food Habits; Income; Focus Groups

\author{
Correspondence \\ G. Ares \\ Instituto Polo Tecnológico de Pando, Facultad de Química, \\ Universidad de la República. \\ By Pass de Rutas 8 y 10, Pando, Canelones 91000, Uruguay. \\ gares@fq.edu.uy \\ 1 Facultad de Química, Universidad de la República, Canelones, \\ Uruguay. \\ 2 Facultad de Psicología, Universidad de la República, \\ Montevideo, Uruguay. \\ ${ }_{3}^{3}$ Escuela de Nutrición, Universidad de la República, \\ Montevideo, Uruguay. \\ 4 Instituto Nacional de Alimentación, Montevideo, Uruguay.
}




\section{Introduction}

The conditions under which people live and work, as well as their lifestyles have been strongly associated with non-communicable diseases (NCDs) 1. In particular, a low intake of fruits and vegetables, together with a high consumption of foods rich in saturated and trans fats, salt and sugar have been reported to be the main cause of a considerable proportion of deaths associated with NCDs 2 . For this reason, interventions aimed at encouraging people to engage in healthier eating habits have been identified as one of the priorities for reducing the burden of NCD 3,4.

Public health interventions aimed at changing dietary patterns tend to focus exclusively on healthy food choices and increasing nutritional knowledge, ignoring the complexity of how people select their food 5. Food choice is a complex phenomenon, which is affected by many interrelated factors, which includes physiological, psychological, economic, social and cultural factors. For this reason, understanding motives underlying food choices and the potential obstacles to changing dietary patterns have been identified as the first steps for the development of interventions and communication campaigns for promoting healthier diets.

The great majority of studies on food choice have been carried out in developed countries 6 . Considering that almost three quarters of all NCD deaths occur in low and middle income countries 7 , research on the food choices of consumers in developing countries, and particularly in Latin American countries, is still needed.

Income is one of the most relevant socio-demographic variables that largely affect consumers' food choices 6,8 , suggesting that the design of interventions aimed at changing dietary patters should take into consideration the characteristics of specific target populations.

Several authors have reported that low-income people tend to have less healthy diets and consequently have higher rates of NCD than middle or high income people 9,10,11,12. Research in high income countries has shown that low-income people usually tend to give more relative importance to price when making their food choices, compared to middle and high income consumers, due to budgetary restrictions and attempts to maximize the amount of food they can buy 13. Furthermore, when making their food choices, low-income individuals tend to buy low-cost products, which are usually calorie-dense and satiating 14,15. A lack of social support, limited access to healthful foods, a lack of cooking skills and of nutritional knowledge have also been reported to be among the main determinants of the eating patterns of low-income populations 16,17,18,19,20,21.

In this context, the aim of the present study was to identify motives underlying food choice and barriers to healthy eating among consumers in two socioeconomic levels in Uruguay.

\section{Methodology}

Eleven focus groups were conducted for this study, each consisting of 5-10 participants. Six of the focus groups were conducted with low-income participants and five with middle income participants. Conducting this number of focus groups enabled to reach a point of saturation, i.e. a point after which no new information was retrieved from the participants 22 . After the 11 focus groups no new information appeared in the discussion and no further groups were planned.

A total of 76 participants from Montevideo, the capital city of Uruguay, took part in the study. The socio-demographic characteristics of the participants are presented in Table 1. Inclusion criteria for the study were that participants were aged between 18 and 70, and were interested and available to participate. Participants from low-income levels were randomly recruited from the database of users of one of the national food stamp programs, administered by the Instituto Nacional de Alimentación (Uruguay). Middle income participants were recruited from the consumer database of the Sensometrics \& Consumer Science research group from Universidad de la República (Uruguay). At the time of recruitment, participants were told that the aim of the study was related to their food consumption habits. The study was approved by the Research Ethics Committee of the School of Chemistry of the Universidad de la República (Uruguay).

Focus group interviews took between 45 and 60 minutes. The moderator had a general line of questioning for leading the interview, which was developed based on previous research 23 . The ques- 
Table 1

Socio-demographic characteristics of focus group participants.

\begin{tabular}{|c|c|c|c|}
\hline \multirow[t]{2}{*}{ Socio-demographic characteristics } & \multicolumn{3}{|c|}{ Percentage of participants } \\
\hline & Total $(\mathrm{N}=76)$ & Low-income $(n=43)$ & Middle-income $(n=33)$ \\
\hline \multicolumn{4}{|l|}{ Gender } \\
\hline Female & 65 & 60 & 70 \\
\hline Male & 35 & 40 & 30 \\
\hline \multicolumn{4}{|l|}{ Age (years) } \\
\hline $18-29$ & 34 & 33 & 37 \\
\hline $30-54$ & 38 & 42 & 33 \\
\hline 55 and older & 28 & 25 & 30 \\
\hline \multicolumn{4}{|l|}{ Education } \\
\hline Incomplete primary school & 17 & 30 & 0 \\
\hline Complete primary school & 17 & 30 & 0 \\
\hline Incomplete secondary school & 22 & 37 & 3 \\
\hline Complete secondary school & 33 & 3 & 73 \\
\hline University & 11 & 0 & 24 \\
\hline \multicolumn{4}{|l|}{ Ocuupation } \\
\hline Worker & 44 & 2 & 100 \\
\hline Retired & 3 & 5 & 0 \\
\hline No productive activity & 53 & 93 & 0 \\
\hline \multicolumn{4}{|l|}{ Numebr of people in the household } \\
\hline 1 & 14 & 14 & 15 \\
\hline 2 & 14 & 0 & 33 \\
\hline $3-4$ & 36 & 23 & 52 \\
\hline More than 4 & 36 & 63 & 0 \\
\hline \multicolumn{4}{|l|}{ Number of children in the household } \\
\hline 0 & 42 & 26 & 64 \\
\hline $1-2$ & 33 & 30 & 36 \\
\hline More than 2 & 25 & 44 & 0 \\
\hline
\end{tabular}

tionnaire included open-ended questions related to the foods frequently consumed, motives underlying their food choices and barriers to healthy eating.

All interviews were conducted by the same researcher. After each focus group, participants were asked to complete a basic socio-demographic questionnaire. Sessions were audio-recorded and then transcribed.

Transcripts of the focus group discussions were analyzed using inductive coding 24 by one of the researchers who authored the work and verified by two additional researchers 25. Disagreements among the researchers were resolved through discussion and agreement about the best code was reached. Interview fragments were arranged into categories and subcategories. Data categories were created as they emerged from examining and reexamining the data. All the data within each category were then compared and analyzed for nuances in meaning. All participant quotes were translated from the original Spanish to English.

\section{Results}

Frequently consumed foods, motives underlying food choice and barriers to healthy eating strongly differed between low and medium income participants. 


\section{Low-income participants}

When asked about the foods that were most commonly consumed, low-income participants mainly mentioned foods rich in complex carbohydrates, such as rice and pasta. The most frequently mentioned dish was stew, which was prepared using rice, lentils, potatoes, carrots, onions, red peppers, pumpkin and tomato sauce. Fruit and raw vegetables received few mentions, as did meat. When low income participants mentioned meat as an ingredient in their dishes, they referred to minced meat or different cuts of beef or chicken with a high proportion of bones.

Five main motives underlying the food choices of low-income participants were identified, as shown in Table 2.

\section{- Economic factors}

Economic factors were the main determinant of food choices of all low-income participants. They referred to different strategies to maximize value for money, primarily measured as the quantity of food they could buy. One of the main strategies was considering price as the main criteria for their food choices, prioritizing it over quality. Participants indicated that they usually buy the cheapest

Table 2

Summary of the main categories that emerged from the analysis of the transcripts of focus group discussions when participants of two income levels discussed the determinants of their food choices. Examples of quotes for each category are provided.

\begin{tabular}{|c|c|}
\hline Income level/Category & Sample quotes \\
\hline \multicolumn{2}{|l|}{ Low-income } \\
\hline \multirow[t]{2}{*}{ Economic factors } & "The pocket rules" \\
\hline & "I don't know; at least in my family it's very hard to have enough money for meat" \\
\hline \multirow[t]{2}{*}{ Satiety } & "Pot food, stew, that type of thing that fills the children up" \\
\hline & $\begin{array}{c}\text { "I vary [the food] every day but rice is always included in the dishes because it is what fills you up } \\
\text { the most" }\end{array}$ \\
\hline \multirow[t]{2}{*}{ Hedonics } & "The oldest does not like stew, so I try to cook something else" \\
\hline & "When they say 'I want a burger', you can't say no. My daughter says that I spoil them" \\
\hline Time available for cooking & $\begin{array}{l}\text { "I eat what I can. I am very busy. While I'm cooking I'm with the baby and when I'm not with the baby, I take the } \\
\text { food from the oven and I do something else, I do homework with the baby. I don't have time... The kids demand } \\
\text { too much because if you leave them for a while they end up fighting. You always have to keep an eye on them" } \\
\text { "Sometimes when there's an emergency and I don't have too much time or money, I go to the grocery store and } \\
\text { buy burgers. A bag or two. To get through the night" }\end{array}$ \\
\hline Nutrient content & "[l eat] lentils, because they have iron. It is one of those dishes that provides a lot of food" \\
\hline \multicolumn{2}{|l|}{ Medium-income } \\
\hline \multirow[t]{2}{*}{ Time available for cooking } & "I eat food that is easy to cook" \\
\hline & $\begin{array}{l}\text { "At night, [I eat] something that is easy to cook or something that I already have. Time is important" } \\
\text { "If I had time I'd prefer to do something else instead of cooking" }\end{array}$ \\
\hline Hedonic aspects & "On Saturdays we eat tastier food than the rest of the week" \\
\hline \multirow[t]{2}{*}{ Variety } & "I try to eat varied food" \\
\hline & "I cook different things because it is boring to eat the same every day, you know?" \\
\hline \multirow[t]{2}{*}{ Nutrient content } & "I try to eat healthy foods" \\
\hline & "I do not eat fried foods" \\
\hline \multirow[t]{2}{*}{ Contextual factors } & $\begin{array}{c}\text { "The family lunch on Saturday and Sunday is when we catch up on the week's news. It values the dish in a } \\
\text { different way" }\end{array}$ \\
\hline & "At night I try to eat lightly, but don't. I have more time, I'm there, I watch TV, and it's worse" \\
\hline
\end{tabular}


products, as well as foods on sale, and reported rarely buying ready-to-eat products due to their relatively high cost, compared to raw food ingredients. They also indicated that the quantity of food they could get with their budgetary restrictions was also maximized by selecting the place where they buy their food, trying to choose local markets over large supermarkets. Economic factors were reported to be the main determinant for not frequently consuming milk, dairy products, fruits and vegetables.

Economic factors were regarded as a barrier for healthy eating and for following medical recommendations. One of the participants said that she could not afford preparing more than one dish for their family and that for that reason her medical condition was not taken into account when deciding what to cook. Although some participants knew that changes in their dietary patterns were necessary, they said that they were not able to make them due to the amount of money available and the higher relative price of healthful food, as exemplified in the following statement: "Uruguayans have a poor diet. It is often not because we don't want to cook; it is due to the lack of money. That's the problem".

\section{- Satisfying hunger}

Another relevant factor among low income participants was the need to eat foods that satisfy hunger and fill them up. Participants said they should buy foods that can be used to feed all household members, especially children, and to fill them up over a long period of time. In particular, participants referred to foods rich in complex carbohydrates such as pasta, rice or stews, prepared with potatoes, as exemplified in Table 2.

Participants strongly associated satiation with healthfulness. Many participants stated that "good food" fills them up for a long period of time and stressed differences between food products and dishes. Food products or dishes with low satiating capacity, such as raw vegetables, were not perceived as good choices, as exemplified by the following statement: "At home we don't make barbecued meat, because barbecued meat does not contain any food. It is better to eat stew that has much more food, especially when there are children".

\section{- Hedonics}

Hedonic aspects were also mentioned by participants as one of the reasons behind their food selection. However, hedonics were not the most relevant factor underlying their food choices as they seemed to compromise on the sensory characteristics of foods for price, as exemplified by the following statement: "One thing is what we'd like to eat and the other is what we can eat".

Hedonic aspects were mainly considered in relation to the children living in the household. Participants stressed that it was important for them that their kids liked the food they prepared and that they sometimes chose their dishes considering the preferences of the children (Table 2).

Foods related to hedonic pleasure were considered "luxuries" or foods consumed in special situations when they were able to purchase them. In this regard, they referred to the need to be able to give their children products linked to social representations, particularly burgers, fries and soft drinks. Participants stated feeling guilty when they were not able to buy these types of foods for their children.

\section{- Convenience}

The time available for cooking was also mentioned by low-income participants when discussing the motives underlying their food choices. In particular, mothers of young children indicated that they faced difficulties in investing time in preparing complex dishes with many food ingredients, as exemplified in Table 2 .

\section{- Nutrient content}

Low income participants also mentioned aspects related to the nutrient content of food as a motive underlying their food choices. However, this factor was not frequently mentioned. Some participants stressed the need to consume healthful foods, conceptualized as foods rich in iron and proteins, and with a low content of fat and saturated fat (Table 2). 


\section{Middle income participants}

Middle income participants spoke of a wider variety of dishes than low income participants, being meat-based preparations, salads, pies and pasta the most frequently mentioned dishes. Participants stated that they regularly ate fruit, vegetables and dairy products.

The main motives underlying the food choices of middle income participants were: time available for cooking, hedonic aspects, nutrient content, variety and contextual variables (Table 2).

\section{- Time available for cooking}

Time available for cooking was the main determinant of food selection for middle income participants. They indicated that they try to minimize the time spent on food preparation, particularly after all the activities of the day, and that in their free time they preferred to do other things rather than cook (Table 2). Middle income participants indicated that they usually buy frozen foods and readymeal products or order take away food, as shown in the following statement: "...frozen food and take away restaurants save me a lot of time".

Convenience in food preparation was prioritized over the sensory and nutritional characteristics of foods, thereby limiting healthy eating patterns. Many participants indicated that despite being aware that they did not have a healthy diet they preferred to prioritize preparation time. In this sense, they complained about the limited variety of ready-to-eat foods and stressed the difficulty in finding practical and nutritious choices: "Frozen food saves a lot of time for other things, and I usually [eat] take away. But you do not have take aways for stew or salad".

Sensory and hedonic aspects, as well as product quality, were often neglected in relation to preparation time, as exemplified by the following quote: "It is also a question of time, because even though it [homemade food] is tastier, I'd rather not cook".

\section{- Hedonic aspects}

Hedonic aspects were a relevant factor underlying the food choices of middle income participants, who highlighted that they try to consume products that they like and that give them pleasure. In particular, they referred to pizzas, pies and hamburgers, when describing products they like. They also stated that the importance they attach to the hedonic aspects of food consumption is greater during the weekend than during the rest of the week.

\section{- Variety}

The need to eat a variety of foods was another factor that determined food selection for middle income participants. They stated that they try to vary the types of food they consume and avoid eating the same food several times a week. Interest in eating a variety of foods was motivated both by the need to have a balanced diet and a desire to avoid boredom (Table 2).

\section{- Nutrient content}

Nutrient content of foods and the perception of healthfulness were also relevant for middle income participants. Participants said that they attempted to consume healthful foods. When referring to specific nutrients, they mainly referred to fat content. As shown in Table 2, some participants mentioned avoiding fried products due to their high fat content as a key strategy related to product healthfulness (Table 2).

\section{- Contextual factors}

Middle income participants indicated that their food selection varies according to several contextual factors, such as time, type of meal, company and the specific situation. They reported that the food 
they ate changed according to the specific time of the year, time of day and day of the week. For example, they referred to pot meals as a dish prepared during winter and not during summer. Participants also mentioned that the food they chose during the weekend was usually different to those they consumed during the week.

The situational context also influenced the way in which they eat and enjoy food. In particular, they stressed that enjoying food consumption and sharing food with family and friends was considered a priority during the weekends (Table 2). Some of the participants stressed that during the weekend they tended to buy food they like at take away restaurants. However, other participants indicated that during weekends they tended to cook more complex dishes or avoid eating ready-to-eat products because they had more free time than during the rest of the week.

Finally, participants emphasized that the activities they perform while eating affected their food decisions and particularly stressed the influence of watching television. According to some participants, watching television made it difficult to follow their desired eating patterns, making them eat more and less healthfully than they wanted to (Table 2).

\section{Discussion}

Overall, results from the present study confirmed the strong influence of income level on motives underlying food choice and barriers to healthy eating, as previously reported in high and middle income countries 8,20,26,27.

Unlike middle income participants, low income participants described their food choices as primarily driven by economic factors, in particular the price of food and the amount of money available. In this socio-economic group, foods mainly seem to be selected to satisfy their hunger and to feel full, given tight household budgets. These results are consistent with those reported in other studies involving low-income participants in high-income countries 13,28,29. Low income participants reported preferring cheap energy-dense food items (particularly starchy foods, such as pasta and rice) over other products that are regarded as less cost-effective in terms of energy density, which partly explain their low self-reported consumption of fruits and vegetables. This strategy has been reported by other authors for low income populations in different countries 15,29,30. In this sense, dietary energy has been reported to be negatively correlated with energy-adjusted dietary costs: the most energy dense diets with the lowest fiber and micronutrient contents are less expensive in terms of energy $(\$ / \mathrm{kcal})$ than higher-quality diets 31 .

An interesting difference between results from the present research and studies conducted with low-income participants in high income countries was related to the low consumption frequency of ready-to-eat products. In the present study, low-income participants reported that they prepared foods from scratch and did not frequently consume ready-to-eat products or eat outside their homes, which can be explained by the high relative cost of these products. On the contrary, research in the United States has shown that fast food restaurants are overrepresented in poor neighborhoods, as they offer large portion sizes at low cost 32 .

Although low-income participants mentioned specific nutrients when discussing their food choices, the conceptualization of "good foods" or healthful foods was strongly linked to satiating capacity. Low-income participants associated food healthfulness with satiation. This led some lowincome participants to consider dishes based on raw vegetables (e.g. salad) as bad food choices because they do not fill them up (Table 2). The strong association between satiation and healthfulness or the concept of "healthful foods" among low-income consumers has not been found in the literature published in high-income countries. For example, low-income African American women in the United States associated starchy foods with weight gain 33 . The strong association between satiation and healthfulness can constitute a barrier to changing the eating patterns of low-income people in Uruguay, in particular for increasing vegetable consumption.

According to low-income participants, hedonic aspects are usually given less importance than economic factors and the satisfaction of hunger, which can be explained by Maslow's hierarchy of needs 34 . According to this model, basic needs, such as satisfying hunger, need to be satisfied before being able to satisfy needs related to pleasure and gratification. In this sense, low income participants 
reported using their money to buy food that satisfies their basic needs (i.e., hunger) before they think of obtaining pleasure from food consumption. Similar results have been reported for low-income participants in high-income countries 13 .

For low-income participants, hedonic aspects were reported to be more salient when selecting foods for the children of the household rather than for adults. These participants stressed that they needed to satisfy children's needs by giving them products that they like due to their sensory characteristics or to their marketing and association with a specific social status (such as soda or burgers). Low-income mothers mentioned that they felt guilty if they were not able to buy their children these types of products. These results are consistent with previous studies that reported the importance of food as a reflection or expression of social status and social identity 35 .

The main motives underlying the food choices of middle income participants markedly differed from those of low income participants. When explaining their food choices, middle income participants did not refer to basic physiological needs, such as satisfying hunger or feeling full. Instead, they referred to other product characteristics, such as convenience, variety, nutrient content and having foods that suit specific contexts. These results suggest that higher needs in Maslow's hierarchy, such as self-esteem and self-actualization, seem to play a relevant role in shaping the food choices of these participants.

Convenience was reported to be the main determinant of food selection for middle income participants, who stressed that they prioritized investing as little time as possible in food preparation. This result is in agreement with previous studies which have identified convenience as the main factor underlying the food choices of middle income Uruguayan participants in specific meal contexts, such as lunch and dinner ${ }^{23}$. Convenience has been regarded as a complex construct which involves saving time and minimizing the physical and mental effort associated with planning and preparing meals 36,37. In the present research, participants referred to a lack of interest in cooking, and a lack of time for planning, cooking and washing the dishes as the main factors that limited their ability to prepare their food from scratch. Interestingly, participants stressed that convenience would still be relevant even if time constraints were not an issue, which indicates a lack of interest in cooking. In this sense, it is important to highlight that the enjoyment of cooking and cooking skills have been associated with balanced food choices 38 .

The importance attributed to convenience and the frequent consumption of ready-to-eat and highly processed products by middle-income participants constitute a relevant barrier for healthy eating patterns. Food products which save time and effort in preparation and consumption have grown in the marketplace 39 and have been reported to contain high fat and sugar contents, associated with obesity and other health problems 40,41 .

Health-related and hedonic factors were also relevant for the food choices of middle income participants. However, these factors might be compromised for convenience. Participants stressed that although they were aware that ready-to-eat products are usually less healthful and tasty than homemade food, they intentionally prioritized preparation time. This is an interesting result considering that sensory and consumer scientists have long stressed hedonics over other non-sensory product characteristics for explaining consumers' food choices 42,43 .

Unlike low income participants, middle income participants also stressed the importance of eating varied food and the influence of contextual factors, such as season, day of the week, and the presence of other people, on their food choices. This is consistent with the argument that context is a key factor in food choice 44 .

\section{Conclusions}

The current study used focus groups to gather information about the motives underlying food choice and barriers to healthy eating among low and middle income consumers in Uruguay. Although this qualitative approach does not make it possible to draw generalizations from the responses and apply them to a larger population, results reinforced the idea that income level should be considered when 
developing effective public policies or interventions aimed at encouraging the adoption of healthy eating patterns.

Convenience was the most relevant barrier towards healthy eating among middle income participants. Therefore, strategies aimed at encouraging people to enjoy cooking and invest more time preparing meals from scratch seem relevant for improving the eating patterns of middle income Uruguayan consumers. This type of strategy can encourage consumers to replace ready-to-eat ultraprocessed products by culinary preparations 45 . A particular focus on developing cooking skills among children and adolescents seems advisable. In this sense, it is important to highlight that meal preparation has been considered a key skill in many dietary interventions 46,47 . Considering the time needed to achieve changes in eating patterns, encouraging the industry to reformulate their products also seems a feasible approach for achieving changes in the fat, salt and sugar intake of this segment of the population over shorter time frames. These strategies have been reported to be successful for reducing salt intake in the United Kingdom 48. However, it is worth taking into account that even if the food industry engages in reformulation strategies, the relationship between consumption of ultra-processed products and non-communicable diseases makes it necessary to develop policies to discourage consumption of these products and encourage their substitution by natural or minimally processed foods, including changes in nutrition label design and regulation of marketing strategies 45,49 . In this sense, it is also important to stress that the development of food and nutrition policies should take into account social, cultural, economic and environmental factors 50,51. In this sense, the consumption of ultra-processed products has been reported to have deleterious effects on local food production systems and biodiversity.

Although the eating patterns of low income participants were mainly determined by economic factors, satiety played a key role. This suggests that differential pricing strategies for low income populations could improve access to healthful products, which are perceived as expensive (e.g. milk, fruit and vegetables). However, low-income participants stressed the need to consume products that fill them up and strongly associated this concept with perceived healthfulness. These results, together with the high importance that middle-income consumers attributed to convenience, suggests that improving access to food by itself would not be enough to improve their nutritional status and encourage healthy eating patterns.

\section{Contributors}

G. Ares, M. R. Curutchet and A. Giménez participated in all stages of the design and execution and the study, data analysis and were responsible for the final version of the manuscript. L. Machín and A. Girona collaborated in data analysis, critical review of the content and approval of the final version.

\section{Acknowledgments}

The authors are indebted to the staff of the Instituto Nacional de Alimentación (Uruguay) for their help with the implementation of the focus groups; and to Espacio Interdisciplinario at the Universidad de la República for financial support. 


\section{References}

1. World Health Organization. Global action plan for the prevention and control of noncommunicable diseases 2013-2020. Geneva: World Health Organization; 2003.

2. World Health Organization. Global health risks: mortality and burden of disease attributable to selected major risks. Geneva: World Health Organization; 2009.

3. Beaglehole R, Bonita R, Horton R, Adams C, Alleyne G, Asaria P, et al. Priority actions for the non-communicable disease crisis. Lancet 2011; 377:1438-47.

4. Strong K, Mathers C, Epping-Jordan J, Beaglehole R. Preventing chronic disease: a priority for global health. Int J Epidemiol 2006; 35:492-4.

5. Sheperd R. The use of the stages of change model with dietary behaviours. In: Sheperd $\mathrm{R}$, Raats M, editors. The psychology of food choice. Wallingford: CABI; 2006. p. 345-56.

6. Hough G, Sosa M. Food choice in low income populations: a review. Food Qual Prefer 2015; 40:334-42.

7. World Health Organization. Global status report on non communicable diseases 2014 . Geneva: World Health Organization; 2014.

8. Marmot M, Wilkinson RG. Social determinants of health. New York: Oxford University Press; 1999.

9. Braveman PA, Cubbin C, Egerter S, Chideya S, Marchi KS, Metzler M, et al. Socioeconomic status in health research: one size does not fit all. JAMA 2005; 294:2879-88.

10. Darmon N, Drewnowski A. Does social class predict diet quality? Am J Clin Nutr 2008; 87:1107-17.

11. Dowler E. Inequalities in diet and physical activity in Europe. Public Health Nutr 2001; 4:701-9.

12. Pan-American Health Organization. Plan of action for the prevention and control of noncommunicable diseases. Washington DC: PanAmerican Health Organization; 2013.

13. Burns C, Cook K, Mavoa H. Role of expendable income and price in food choice by low income families. Appetite 2013; 71:209-17.

14. Drewnoski A. Obesity and the food environment: dietary energy density and diet costs. Am J Prev Med 2004; 27(3 Suppl):154-62.

15. Drenowski A, Darmon N. The economics of obesity: dietary energy density and energy cost. Am J Clin Nutr 2005; 82(1 Suppl):265S$73 \mathrm{~S}$.
16. Appelhans BM, Waring ME, Schneider KL, Pagoto SL. Food preparation supplies predict children's family meal and home-prepared dinner consumption in low-income households. Appetite 2014; 76:1-8.

17. Cortés DE, Millán-Ferro A, Schneider K, Vega RR, Caballero AE. Food purchasing selection among low-income, Spanish-speaking Latinos. Am J Prev Med 2013; 44(3 Suppl 3):S267-73.

18. Cummins S, Macintyre S. Food environments and obesity: neighbourhood or nation? Int J Epidemiol 2006; 35:100-4.

19. Hendrie GA, Coveney J, Cox D. Exploring nutrition knowledge and the demographic variation in knowledge levels in an Australian community sample. Public Health Nutr 2008; 11:1365-71.

20. Inglis V, Ball K, Crawford D. Why do women of low socioeconomic status have poorer dietary intake behaviors than women of higher socioeconomic status? A qualitative exploration. Appetite 2005; 45:334-43.

21. Wang Y, Beydoun MA. The obesity epidemic in the U.S. - gender, age, socioeconomic, racial/ethnic, and demographic characteristics: a systematic review and meta-regression analysis. Epidemiol Rev 2007; 29:6-28.

22. Strauss AL, Corbin JM. Basics of qualitative research: techniques and procedures for developing grounded theory. Thousand Oaks: Sage Publications; 1998.

23. Machín L, Giménez A, Vidal L, Ares G. Influence of context on motives underlying food choice. J Sens Stud 2014; 29:313-24.

24. Hennink M, Hutter I, Bailey A. Qualitative research methods. London: Sage Publications; 2011.

25. Brug J, Lechner L, De Vries H. Psychosocial determinants of fruit and vegetable consumption. Appetite 1995; 25:285-96.

26. Shahar D, Shai I, Vardi H, Shahar A, Fraser D Diet and eating habits in high and low socioeconomic groups. Nutrition 2005; 21:559-66.

27. Sosa M, Cardina P, Contarini A, Hough G. Food choice and emotions: comparison between low and middle income populations. Food Res Int 2015; 76:253-60.

28. Wiig K, Smith C. The art of grocery shopping on a food stamp budget. Factors influencing the food choices of low-income women as they try to make ends meet. Public Health Nutr 2009; 12:1726-34. 
29. Antin TMJ, Hunt G. Food choice as a multidimensional experience: a qualitative study with young African American women. Appetite 2012; 58:856-63.

30. Stewart H, Hyman J, Frazão E, Buzby JC, Carlson A. Can low-income Americans afford to satisfy my pyramid fruit and vegetable guidelines? J Nutr Educ Behav 2011; 43:173-9.

31. Monsivais P, Drewnowski A. Lower-energydensity diets are associated with higher monetary costs per kilocalorie and are consumed by women of higher socioeconomic status. J Am Diet Assoc 2009; 109:814-22.

32. Powell LM, Chaloupka FJ, Bao Y. The availability of fast-food and full-service restaurants in the United States: associations with neighborhood characteristics. Am J Prev Med 2007; 33(4 Suppl):S240-5.

33. Lynch EB, Holmes S, Kiem K, Koneman SA. Concepts of healthful food among low-income African American women. J Nutr Educ Behav 2012; 44:154-9.

34. Maslow AH. A theory of human motivation. Psychol Rev 1948; 50:370-96.

35. Devine C, Sobal J, Bisogni C, Connors M. Food choices in three ethnic groups: interactions of ideals, identities and roles. J Nutr Educ 1999; 31:86-93.

36. Bava CM, Jaeger SR, Park J. Constraints upon food provisioning practices in "busy" women's lives: trade-offs which demand convenience. Appetite 2008; 50:486-98.

37. Scholderer J, Grunert K. Consumers, food and convenience: the long way from resource constraints to actual consumption patterns. J Econ Psychol 2005; 26:105-28.

38. Hartmann C, Dohle S, Siegrist M. Importance of cooking skills for balanced food choices. Appetite 2013; 65:125-31.

39. Guthrie JF, Lin BH, Frazao E. Role of food prepared away from home in the American diet, 1977-78 versus 1994-96: changes and consequences. J Nutr Educ Behav 2002; 34:140-50.

40. Monteiro CA. Nutrition and health: the issue is not food, nor nutrients, so much as processing. Public Health Nutr 2009; 12:729-31.

41. Monteiro CA, Moubarac JC, Cannon G, Ng SW, Popkin B. Ultra-processed products are becoming dominant in the global food system. Obes Rev 2013; 14 Suppl 2:21-8.
42. Rosas-Nexticapa M, Angulo O, O’Mahony M. How well does the 9-point hedonic scale predict purchase frequency? J Sens Stud 2005; 20:313-31.

43. Vehkalahti K, Tahvonen R, Tuorila H. Hedonic responses and individual definitions of an ideal apple as predictors of choice. J Sens Stud 2013; 28:346-57.

44. Meiselman HL. Experiencing food products within a physical and social context. In: Schifferstein HNJ, Hekkert P, editors. Product experience. Oxford: Elsevier; 2008. p. 559-80.

45. Pan American Health Organization. Ultraprocessed food and drink products in Latin America: trends, impact on obesity, policy implications. Washington DC: Pan American Health Organization; 2015.

46. Alexander AG, Grant WL, Pedrino KJ, Lyons PE. A prospective multifactorial intervention on subpopulations of predominately Hispanic children at high risk for obesity. Obesity (Silver Spring) 2014; 22:249-53.

47. Archuleta M, Vanleeuwen D, Halderson K, Jackson K, Bock MA, Eastman W, et al. Cooking schools improve nutrient intake patterns of people with type 2 diabetes. J Nutr Educ Behav 2012; 44:319-25.

48. Wyness LA, Butriss JL, Stanner SA. Reducing the population's sodium intake: the UK Food Standards Agency's salt reduction programme. Public Health Nutr 2011; 15:254-61.

49. Monteiro CA, Moubarac J-C, Cannon G, Ng $\mathrm{S}$, Popkin B. Ultra-processed products are becoming dominant in the global food system. Obes Rev 2013; 14:21-8.

50. Lang T, Barling D, Caraher M. Food policy: integrating health, environment and society. Oxford: Oxford University Press; 2009.

51. Cannon G, Leitzmann C. The new nutrition science project. Public Health Nutr 2005; 8:673-94. 


\section{Resumen}

Las intervenciones dirigidas a lograr cambios en los patrones alimentarios deben ser planeadas en base a los principales motivos responsables de las elecciones alimentarias de las poblaciones-objetivo. El objetivo del estudio fue identificar los motivos responsables de las elecciones alimentarias y las barreras para una alimentación saludable entre consumidores de dos niveles de ingreso en Uruguay. Se realizaron once grupos focales, con un total de 76 participantes. Seis grupos incluyeron participantes de ingreso bajo, y los otros cinco, participantes de ingreso medio. Las discusiones se realizaron en torno a los productos alimentarios más frecuentemente consumidos, los motivos responsables de las elecciones alimentarias y las barreras contra la alimentación saludable. Los resultados confirmaron la fuerte influencia del nivel de ingreso sobre los motivos responsables de las elecciones alimentarias y las barreras para la adopción de la alimentación saludable. Los participantes de ingreso bajo relataron que sus elecciones estaban orientadas principalmente por factores económicos $y$ por la saciedad, mientras que los participantes de ingreso medio citaron la conveniencia como el principal determinante de la elección de alimentos. Las implicaciones para la elaboración de políticas públicas dirigidas a cada grupo de ingreso son discutidas.

Hábitos Alimenticios; Renta; Grupos Focales

\section{Resumo}

As intervenções dirigidas a mudanças nos padrões alimentares devem ser planejadas com base nos principais motivos subjacentes às escolhas alimentares entre populações-alvo específicas. O objetivo do estudo foi identificar os motivos subjacentes às escolhas alimentares $e$ as barreiras contra a alimentação saudável entre consumidores de duas faixas de renda no Uruguai. Foram realizados 11 grupos focais, com um total de 76 participantes. Seis grupos incluíram participantes de baixa renda, e os outros cinco, participantes de renda média. As discussões versaram sobre os produtos alimentares mais frequentemente consumidos, os motivos por trás das escolhas alimentares e as barreiras contra a alimentação saudável. Os resultados confirmaram a forte influência do nível de renda sobre os motivos subjacentes às escolhas alimentares e as barreiras contra a adoção da alimentação saudável. Os participantes de renda baixa relataram que suas escolhas eram orientadas principalmente por fatores econômicos e pela saciedade, ao contrário dos participantes de renda média, que citaram a conveniência como o principal determinante da escolha de alimentos. Os autores discutem as implicações para a elaboração de politicas públicas dirigidas a cada grupo de renda.

Hábitos Alimentares; Renda; Grupos Focais
Submitted on 20/Dec/2015

Final version resubmitted on 14/Jun/2016 Approved on 24/Jun/2016 